\title{
Determination of eutrophic areas in Mundaú/Manguaba lagoons, Alagoas-Brazil, through studies of the phytoplanktonic community
}

\author{
Melo-Magalhães, EM.*, Medeiros, PRP., Lira, MCA., Koening, ML. and Moura, AN. \\ Laboratórios Integrados de Ciências do Mar e Naturais, \\ Universidade Federal de Alagoas - UFAL, \\ Rua Aristeu de Andrade, 452, Farol, CEP 57021-090, Maceió, AL, Brazil \\ *e-mail: enaidemmm@gmail.com
}

Received June 25, 2007 - Accepted August 17, 2007 - Distributed May 31, 2009

(With 2 figures)

\begin{abstract}
Mundaú and Manguaba Lagoons ( $9^{\circ} 34^{\prime} 38^{\prime \prime}-9^{\circ} 45^{\prime} 30^{\prime \prime} \mathrm{S}$ and $35^{\circ} 44^{\prime} 00^{\prime \prime}-35^{\circ} 58^{\prime} 13^{\prime \prime} \mathrm{W}$ ) are considered the largest and most productive ones in the state of Alagoas and were studied with the purpose of identifying the existence of anthropic impacts. Samples were collected at 8 stations, during low tide and flooding in rainy and dry periods, using the "Van Dorn" bottle and plankton net. In total, 155 taxons were identified, with special emphasis on Bacillariophyta and Cyanophyta divisions. The most abundant species in Mundaú Lagoon was Skeletonema cf. costatum, and in the Manguaba Lagoon, Cyclotella meneghiniana, Microcystis aeruginosa and Anabaena spiroides. The diversity ranged from 0.17 bits cell/L to 4.81 bits cell/L. The predominance of freshwater species (51\%), evidenced higher influence of the limnetic flow on the two environments studied. The high values related to the phytoplanktonic density characterize the lagoons as strongly impacted environments, indicating the existence of eutrophic conditions in most of the studied stations.
\end{abstract}

Keywords: phytoplankton, ecology, density, Mundaú/Manguaba lagoons.

\section{Determinação de áreas eutróficas nas lagoas Mundaú e Manguaba, Alagoas-Brasil, através de estudos com a comunidade fitoplanctônica}

\section{Resumo}

As lagunas Mundaú e Manguaba ( $9^{\circ} 34^{\prime} 38^{\prime \prime}-9^{\circ} 45^{\prime} 30^{\prime \prime}$ S e $35^{\circ} 44^{\prime} 00^{\prime \prime}-35^{\circ} 58^{\prime} 13^{\prime \prime} \mathrm{W}$ ) são consideradas as maiores e mais produtivas do Estado de Alagoas e foram estudadas com o objetivo de identificar a existência de impactos antrópicos, nos períodos chuvoso e seco, com base na composição, diversidade e densidade fitoplanctônica. Coletas de material fitoplanctônico foram realizadas em 8 estações fixas, durante maré vazante e enchente nos períodos chuvoso e seco. As amostras foram coletadas com garrafa de "Van Dorn" e rede de plâncton. Foram identificados 155 táxons destacando-se as divisões Bacillariophyta e Cyanophyta. A espécie mais abundante na laguna Mundaú foi Skeletonema cf. costatum; na laguna Manguaba foram Cyclotella meneghiniana, Microcystis aeruginosa e Anabaena spiroides. A diversidade oscilou ente 0,17 bits cell/L e 4,81 bits cell/L. A predominância de espécies dulciaquícolas, (51\%) evidenciou maior influência do fluxo limnético nos dois ambientes estudados. Os altos valores da densidade fitoplanctônica caracterizam as lagunas como ambientes fortemente impactados, indicando a existência de condições eutróficas na maioria das estações estudadas.

Palavras-chave: fitoplâncton, ecologia, densidade, lagunas Mundaú/Manguaba.

\section{Introduction}

The Mundau/Manguaba Estuarine-Lagoon Complex $\left(9^{\circ} 34^{\prime} 38^{\prime \prime}-9^{\circ} 45^{\prime} 30^{\prime \prime} \mathrm{S}\right.$ and $\left.35^{\circ} 44^{\prime} 00^{\prime \prime}-35^{\circ} 58^{\prime} 13^{\prime \prime} \mathrm{W}\right)$ is composed of two large lagoons: Mundaú and Manguaba, which are interconnected by waterways that converge on a single dam (Figure 1). These lagoons are considered the largest and the most productive in the state of Alagoas.
In estuarine systems, the distribution, composition and density of phytoplanktonic populations, their seasonal and spatial variations are controlled mainly by factors such as tolerance to salinity, luminosity, nutrients and grazing (Kinne, 1970; Santelices, 1977). The geomorphologic characteristics, the anthropogenic impacts and the variations in the weather conditions are other 


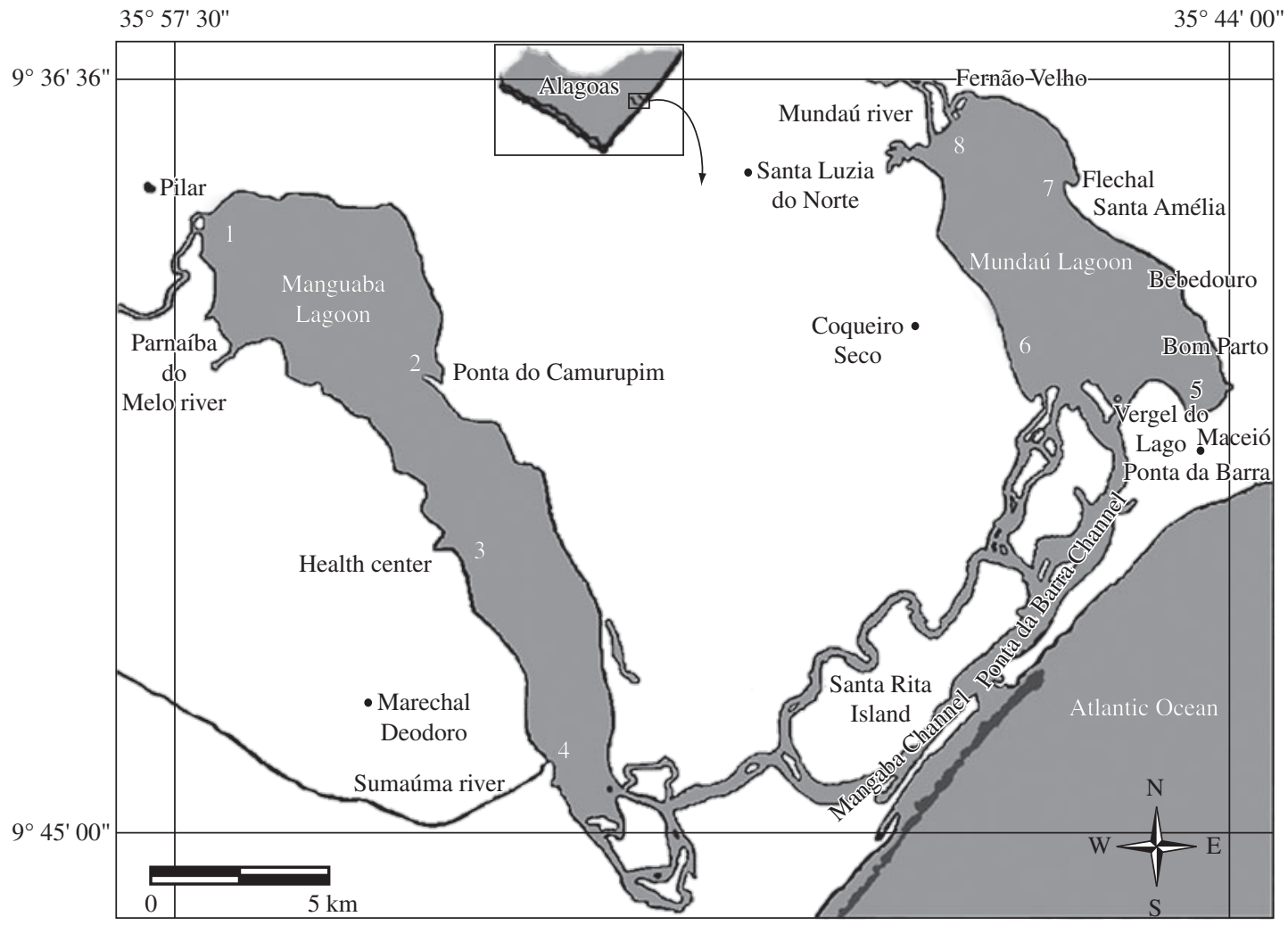

Figure 1. Map of the Mundau/Manguaba Estuarine-Lagoon Complex showing the sampling stations.

factors that establish the taxonomic characteristics and the spatial-temporal dynamics of their communities (Brandini, 1997).

However, the increased phytoplanktonic biomass resulting from the higher eutrophization of these ecosystems provokes, according to Margalef (1991), the substitution of their species and reduced specific diversity, thus changing all the trophic web of the ecosystem.

The taxonomic inventories for the phytoplanktonic community that have been established so far in the Mundau/Manguaba Estuarine-Lagoon Complex reveal the occurrence of elevated specific variety (Eskinazi-Leça and Santana, 1977; 1978; Sardeiro, 1987; Melo-Magalhães and Navarro, 1994; MeloMagalhães et al., 1998; Melo-Magalhães et al., 2004a). Regarding the phytoplanktonic density and biomass, the only known studies are: the ecological/cultural study of CELMM (Alagoas, 1980) and the study conducted by Melo-Magalhães et al. (2004a), which determine the phytoplanktonic composition, biomass and density in the Mundau/Manguaba Estuarine-Lagoon Complex channels.

The purpose of this study was to identify, based on the phytoplanktonic composition, diversity and density, the existence of anthropic impacts in both lagoons, during the rainy and dry periods.

\section{Materials and Methods}

Samples of the phytoplanktonic material were collected at 8 fixed stations of Manguaba and Mundaú Lagoons (Figure 1), during low tide and flooding in rainy and dry periods. For the phytoplanktonic density and biomass study, the water was collected from the superficial area, with the help of a Van Dorn-type bottle, and for the specific composition study, abundance and diversity, the samples were collected with a plankton net of $45 \mu \mathrm{m}$ mesh (fixed with formaldehyde, $4 \%$ neutralized).

The determination of cellular density (cell/L) was performed according to the Utermöhl method (Hasle, 1978).

For the identification of taxa, aliquot samples $(0.5 \mathrm{~mL})$ were examined in binocular microscope, with enlargement of 100 and 400 times. The identification was based on specific bibliographies.

The taxa-related abundance was determined according to Lobo and Leighton (1986). The specific diversity rate was calculated according to Shannon (H') (1948). Equitability (J) was calculated according to Pielou (1977).

\section{Results}

The microphytoplankton corresponded to 155 taxa in both lagoons, in the two studied periods, and was 
represented by Cyanophyta (31), Euglenophyta (7), Dinophyta (3), Bacillariophyta (90) and Chlorophyta (24) divisions.

Most species identified in both lagoons and in the two studied periods were of freshwater origin (51\%). The species of neritic or neritic/marine origin represented $47 \%$. Only $2 \%$ of the species were of estuarine origin (Table 1).

Among the freshwater organisms, the planktonic species $(\mathrm{P})$ represented the largest part of the microphytoplankton, while the taxa of marine origin were mostly tychoplanktonic species (TP), Table 1.

The dominant species, defined as numerically over $70 \%$, were detected in Manguaba Lagoon, characteristic of freshwater environments, such as Anabaena spiroides Klebahn, Microcystis aeruginosa (Kützing) Kützing and Cyclotella meneghiniana Kützing; while in Mundaú Lagoon, where the salinity levels were higher, the predominant species were diatoms: Skeletonema $\mathrm{cf}$. costatum (Greville) Cleve and Nitzschia sigma (Kützing) Wm.Smith (Table 1).

The specific diversity ranged from 0.17 bits cell/L to 4.81 bits cell/L. In Manguaba Lagoon, the specific diversity was considered as very low at the stations where predominant species occurred, such as Microcystis aeruginosa at stations 2 and 3, during the rainy period, and Anabaena spiroides at station 2, in the dry period. In Mundaú Lagoon, the low diversities observed mainly at stations 5 and 6 were related to blooms of Skeletonema cf. costatum that occurred in the two studied periods.

The phytoplanktonic density study in Mundaú and Manguaba Lagoons revealed the occurrence of cyanophyta, euglenophyta, dinoflagellate, diatoms, phytoflagellate and chlorophyta, observing a great variation in the cellular density of the phytoplankton when comparing the two lagoons (Mundaú and Manguaba) and the two studied periods (dry and rainy), with higher values obtained in Manguaba Lagoon in the dry period (September and November).

In Manguaba Lagoon, the phytoplanktonic density values ranged from $12 \times 10^{4}$ cell/L to $992 \times 10^{4}$ cell/L, observed in the dry period. In Mundaú Lagoon, the values were lower and ranged from $11 \times 10^{4}$ cell/L in the rainy period to $593 \times 10^{4}$ cell/L in the dry period (Figure 2 ).

The highest densities of the cyanophyta group were observed in Manguaba Lagoon, mainly in the flood period at station 3, in May, which represented $462 \times 10^{4}$ cell/L. On this occasion, the predominance of Microcystis aeruginosa was observed (Table 1). Another high occurrence of cyanophyta $\left(607 \times 10^{4}\right.$ cell/L) was observed, also in this lagoon, specifically in the flood period at station 3 in September, represented by Anabaena spiroides species. In Mundaú Lagoon, the maximum density shown by this group was $101 \times 10^{4}$ cell/L, observed in the flood period at station 6 in May. At this station, the most abundant cyanophyta species was Oscillatoria sancta (Table 1).
The highest densities shown by the group of diatoms in Manguaba Lagoon were in July, during low tide at station 2, with $619 \times 10^{4}$ cell/L, and in September, in the flood period at station 3 , presenting $373 \times 10^{4}$ cell/L. In both of these collected samples, Cyclotella meneghiniana species was considered abundant (Table 1).

In Mundaú Lagoon, the highest densities of diatoms were observed in September, during low tide at stations 5, with $468 \times 10^{4} \mathrm{cell} / \mathrm{L}$, and in the flood period at station 8 , with $279 \times 10^{4}$ cell/L, where a great abundance of Skeletonema cf. costatum was observed (Table 1).

\section{Discussion}

The phytoplanktonic organisms are the base of the trophic web in water systems, forming a different group from almost all taxonomic groups. When defining the trophic characterization of water environments, the composition, abundance, biomass and diversity of the phytoplanktonic organisms are used as water quality indicators (De León and Chalar, 2003).

In this study, the phytoplanktonic community was composed of 155 taxa, 58\% of which were diatoms, and $20 \%$ were cyanophyceae, which showed the qualitative importance of these groups in the waters of Manguaba and Mundaú Lagoons. The predominance of diatoms in the phytoplanktonic community has been previously mentioned concerning the Mundau/ Manguaba Estuarine-Lagoon Complex in the studies conducted by Melo-Magalhães and Navarro (1994) and Melo-Magalhães et al. (2004a). According to Egge and Aksnes, 1992; Patrick, 1967, the dominance of these microalgae is provoked mainly by their high growth rate if compared to the phytoplanktonic groups, their eurialine nature and preference for eutrophic environments, peculiar to the estuarine ecosystems.

In addition, the cyanophyceae substantially contributed to the increase of flora composition, representing the second most important group in the aspect of species variety.

The Skeletonema cf. costatum species, dominant in Mundau Lagoon, is one of the most common neritic diatoms in the world, easily found in salty waters, near the discharge of rivers. This organism, although planktonic, is an example of neritic benthonic species, and can live either in sediment or in suspension, where it develops, forming blooms (Round, 1981). The occurrence of this species has been observed in other environments in the state of Alagoas, such as at the discharge of São Francisco River (Eskinazi-Leça, 1967; 1969); at Parque Municipal Marinho de Paripueira, (Melo-Magalhães et al., 1999), where this microalga was considered of little importance, and at the Continental Platform in the states of Alagoas and Sergipe (Sardeiro and Eskinazi-Leça, 1985), this species being considered as not frequent. In Mundaú Lagoon, this microalga was mentioned by Eskinazi-Leça and Santana (1977; 1978), Melo-Magalhães and Navarro (1994). However, the quantitative contribution of this 
Table 1. Synopsis and ecological data of taxa identified during the studied period at stations in Manguaba and Mundaú Lagoons. R = Rainy Period; D = Dry Period; P = Planktonic; TP = Thychoplanktonic; $\mathrm{X}=$ Taxa occurrence; --- = Taxa absence; $\bigcirc=$ Freshwater; $\diamond=$ Neritic Marine: $+=$ Neritic/Oceanic Marine; $\bullet=$ Estuarine; $\square=$ Dominant species; and = Abundant species.

\begin{tabular}{|c|c|c|c|c|c|c|c|c|c|c|c|}
\hline & & \multicolumn{2}{|c|}{ Manguaba } & \multicolumn{2}{|c|}{ Mundaú } & & & \multicolumn{2}{|c|}{ Manguaba } & \multicolumn{2}{|c|}{ Mundaú } \\
\hline & & $\mathbf{R}$ & D & $\mathbf{R}$ & D & & & $\mathbf{R}$ & D & $\mathbf{R}$ & D \\
\hline CYANOPHYTA & & & & & & BACILLARIOPHYTA & & & & & \\
\hline $\begin{array}{l}\text { Anabaena circinalis } \\
\text { Rabenhorst ex } \\
\text { Bornet and Flahault }\end{array}$ & $\bigcirc$ & $\mathrm{P}$ & $\mathrm{P}$ & $\mathrm{P}$ & $\mathrm{P}$ & $\begin{array}{l}\text { Achnanthes brevipes } \\
\text { Agardh }\end{array}$ & + & $\mathrm{TP}$ & $\mathrm{TP}$ & $\mathrm{TP}$ & $\mathrm{TP}$ \\
\hline $\begin{array}{l}\text { Anabaena spiroides } \\
\text { Klebahn }\end{array}$ & $\bigcirc$ & $\mathrm{P}$ & $\mathrm{P}$ & $\mathrm{P}$ & $\mathrm{P}$ & $\begin{array}{l}\text { Achnanthes longipes } \\
\text { Agardh }+\end{array}$ & & $\mathrm{TP}$ & --- & $\mathrm{TP}$ & --- \\
\hline $\begin{array}{l}\text { Anabaenopsis circularis } \\
\text { Klebahn }\end{array}$ & $\bigcirc$ & $\mathrm{P}$ & $\mathrm{P}$ & $\mathrm{P}$ & $\mathrm{P}$ & $\begin{array}{l}\text { Actinocyclus normanii } \\
\text { (Gregory) Hustedt }\end{array}$ & + & $\mathrm{P}$ & $\mathrm{P}$ & $\mathrm{P}$ & $\mathrm{P}$ \\
\hline $\begin{array}{l}\text { Aphanizomenon gracile } \\
\text { (Lemm.) Lemm }\end{array}$ & $\bigcirc$ & $\mathrm{P}$ & $\mathrm{P}$ & $\mathrm{P}$ & $\mathrm{P}$ & $\begin{array}{l}\text { Actinocyclus roperii } \\
\text { (Bréb.) Grunow }\end{array}$ & + & --- & --- & --- & $\mathrm{TP}$ \\
\hline $\begin{array}{l}\text { Aphanocapsa delicatissima } \\
\text { West and G. S. West }\end{array}$ & $\bigcirc$ & $\mathrm{P}$ & --- & $\mathrm{P}$ & --- & $\begin{array}{l}\text { Actinoptychus senarius } \\
\text { (Ehrenb.) Ehrenberg }\end{array}$ & + & --- & $\mathrm{TP}$ & --- & $\mathrm{TP}$ \\
\hline $\begin{array}{l}\text { Aphanocapsa incerta } \\
\text { (Lemm.) Cronberg and } \\
\text { Komárek }\end{array}$ & $\bigcirc$ & $\mathrm{P}$ & --- & --- & $\mathrm{P}$ & $\begin{array}{l}\text { Actinoptychus splendens } \\
\text { (Shadbolt) Ralfs }\end{array}$ & + & --- & --- & --- & $\mathrm{TP}$ \\
\hline $\begin{array}{l}\text { Arthrospira skujae } \\
\text { Magrin, Senna and Komárek }\end{array}$ & $\bigcirc$ & $\mathrm{P}$ & $\mathrm{P}$ & $\mathrm{P}$ & --- & $\begin{array}{l}\text { Amphora angusta } \\
\text { (Gregory) De Toni }\end{array}$ & + & $\mathrm{TP}$ & $\mathrm{TP}$ & $\mathrm{TP}$ & $\mathrm{TP}$ \\
\hline Chroococcus sp. & & $\mathrm{X}$ & $X$ & --- & $X$ & $\begin{array}{l}\text { Amphora laevis } \\
\text { Gregory }\end{array}$ & + & --- & --- & --- & $\mathrm{TP}$ \\
\hline Coelosphaerium sp. & & $\mathrm{X}$ & $\mathrm{X}$ & $\mathrm{X}$ & --- & Amphora sp. & & --- & $\mathrm{X}$ & --- & $\mathrm{X}$ \\
\hline $\begin{array}{l}\text { Cylindrospermopsis raciborskii } \\
\text { (Wolosz.) Seen. et } \\
\text { S. Raju i }\end{array}$ & $\bigcirc$ & $\mathrm{P}$ & $\mathrm{P}$ & $\mathrm{P}$ & --- & $\begin{array}{l}\text { Asterionellopsis glacialis } \\
\text { (Castracane) Round }\end{array}$ & $\diamond$ & --- & $\mathrm{P}$ & --- & --- \\
\hline $\begin{array}{l}\text { Geitlerinema unigranulatum } \\
\text { (Singh) Komárek and Azevedo }\end{array}$ & & $\mathrm{P}$ & --- & --- & --- & $\begin{array}{l}\text { Aulacoseira ambigua } \\
\text { (Grunow) Simonsen }\end{array}$ & O & $\mathrm{P}$ & --- & $\mathrm{P}$ & --- \\
\hline $\begin{array}{l}\text { Limnothrix planctonica } \\
\text { (Singh) Komárek and Azevedo }\end{array}$ & & $\mathrm{P}$ & --- & $\mathrm{P}$ & $\mathrm{P}$ & $\begin{array}{l}\text { Aulacoseira granulata } \\
\text { (Ehrenb.) Simonsen }\end{array}$ & $\bigcirc$ & $\mathrm{P}$ & $\mathrm{P}$ & $\mathrm{P}$ & $\mathrm{P}$ \\
\hline Lyngbya sp. & & --- & --- & $\mathrm{X}$ & --- & $\begin{array}{l}\text { Bacillaria paxillifera } \\
\text { (Müller) Hendey }\end{array}$ & + & $\mathrm{TP}$ & $\mathrm{TP}$ & --- & --- \\
\hline $\begin{array}{l}\text { Merismopedia tenuissima } \\
\text { Lemm. }\end{array}$ & $\bigcirc$ & $\mathrm{P}$ & --- & $\mathrm{P}$ & --- & $\begin{array}{l}\text { Bellerochea malleus } \\
\text { (Bright.) V. Heurk }\end{array}$ & + & $\mathrm{P}$ & $\mathrm{P}$ & $\mathrm{P}$ & $\mathrm{P}$ \\
\hline $\begin{array}{l}\text { Microcystis aeruginosa } \\
\text { (Kützing) Kützing }\end{array}$ & $\bigcirc$ & $\mathrm{P}$ & $\mathrm{P}$ & $\mathrm{P}$ & --- & $\begin{array}{l}\text { Biddulphia biddulphiana } \\
\text { (Smith) Boyer }\end{array}$ & + & $\mathrm{TP}$ & --- & $\mathrm{TP}$ & --- \\
\hline $\begin{array}{l}\text { M. panniformis } \\
\text { Komárek et al. }\end{array}$ & $\bigcirc$ & $\mathrm{P}$ & $\mathrm{P}$ & $\mathrm{P}$ & --- & $\begin{array}{l}\text { Biddulphiopsis titiana } \\
\text { Grunow }\end{array}$ & + & --- & --- & --- & $\mathrm{P}$ \\
\hline $\begin{array}{l}\text { M. protocystis } \\
\text { Crow }\end{array}$ & $\bigcirc$ & $\mathrm{P}$ & --- & --- & --- & $\begin{array}{l}\text { Campylodiscus clypeus } \\
\text { Ehrenberg }\end{array}$ & + & $\mathrm{TP}$ & $\mathrm{TP}$ & $\mathrm{TP}$ & \\
\hline $\begin{array}{l}\text { M. wesenbergii } \\
\text { (Komárek) Komárek }\end{array}$ & $\bigcirc$ & $\mathrm{P}$ & --- & $\mathrm{P}$ & $\mathrm{P}$ & $\begin{array}{l}\text { Cerataulus smithii } \\
\text { Ralph in Pritchard }\end{array}$ & + & $\mathrm{TP}$ & --- & $\mathrm{TP}$ & --- \\
\hline $\begin{array}{l}\text { Oscillatoria proboscidea } \\
\text { Gomont }\end{array}$ & $\bigcirc$ & $\mathrm{TP}$ & --- & --- & --- & $\begin{array}{l}\text { Cerataulus turgidus } \\
\text { Ehrenberg }\end{array}$ & + & --- & --- & $\mathrm{TP}$ & --- \\
\hline O. sancta ex Gomont & $\bigcirc$ & $\mathrm{TP}$ & $\mathrm{TP}$ & $\mathrm{TP}$ & $\mathrm{TP}$ & Chaetoceros sp. & & $\mathrm{X}$ & $\mathrm{X}$ & --- & $\mathrm{X}$ \\
\hline $\begin{array}{l}\text { O. simplicissima } \\
\text { Gomont }\end{array}$ & $\bigcirc$ & $\mathrm{TP}$ & --- & $\mathrm{TP}$ & --- & $\begin{array}{l}\text { Climacosphenia moniligera } \\
\text { (Lyngbye) Kützing + }\end{array}$ & & $\mathrm{TP}$ & $\mathrm{TP}$ & $\mathrm{TP}$ & $\mathrm{TP}$ \\
\hline $\begin{array}{l}\text { O. subbrevis } \\
\text { Schm }\end{array}$ & $\bigcirc$ & $\mathrm{TP}$ & --- & $\mathrm{TP}$ & --- & $\begin{array}{l}\text { Cocconeis scutellum } \\
\text { Ehrenberg }\end{array}$ & + & $\mathrm{TP}$ & $\mathrm{TP}$ & $\mathrm{TP}$ & --- \\
\hline
\end{tabular}


Table 1. Continued...

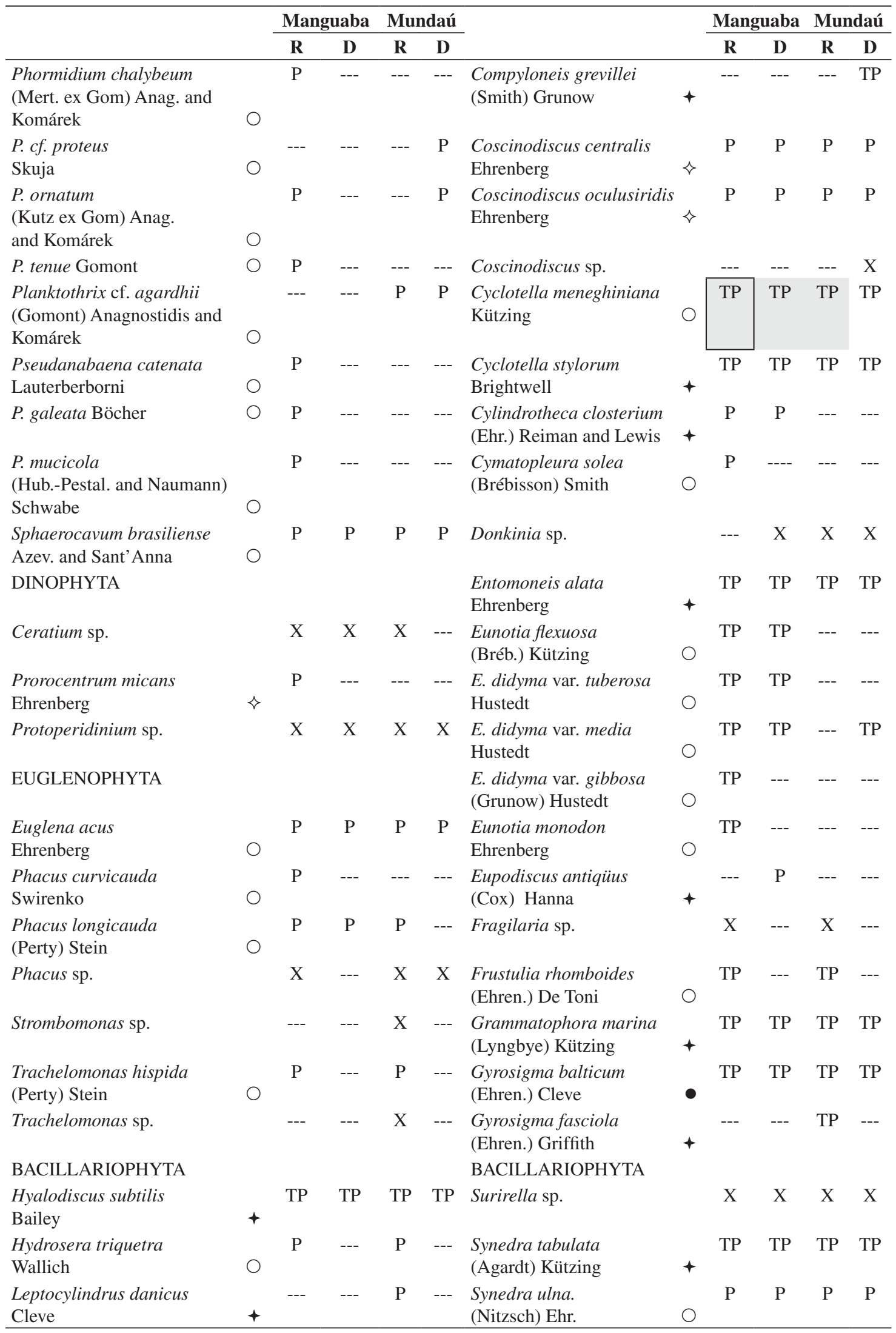


Table 1. Continued...

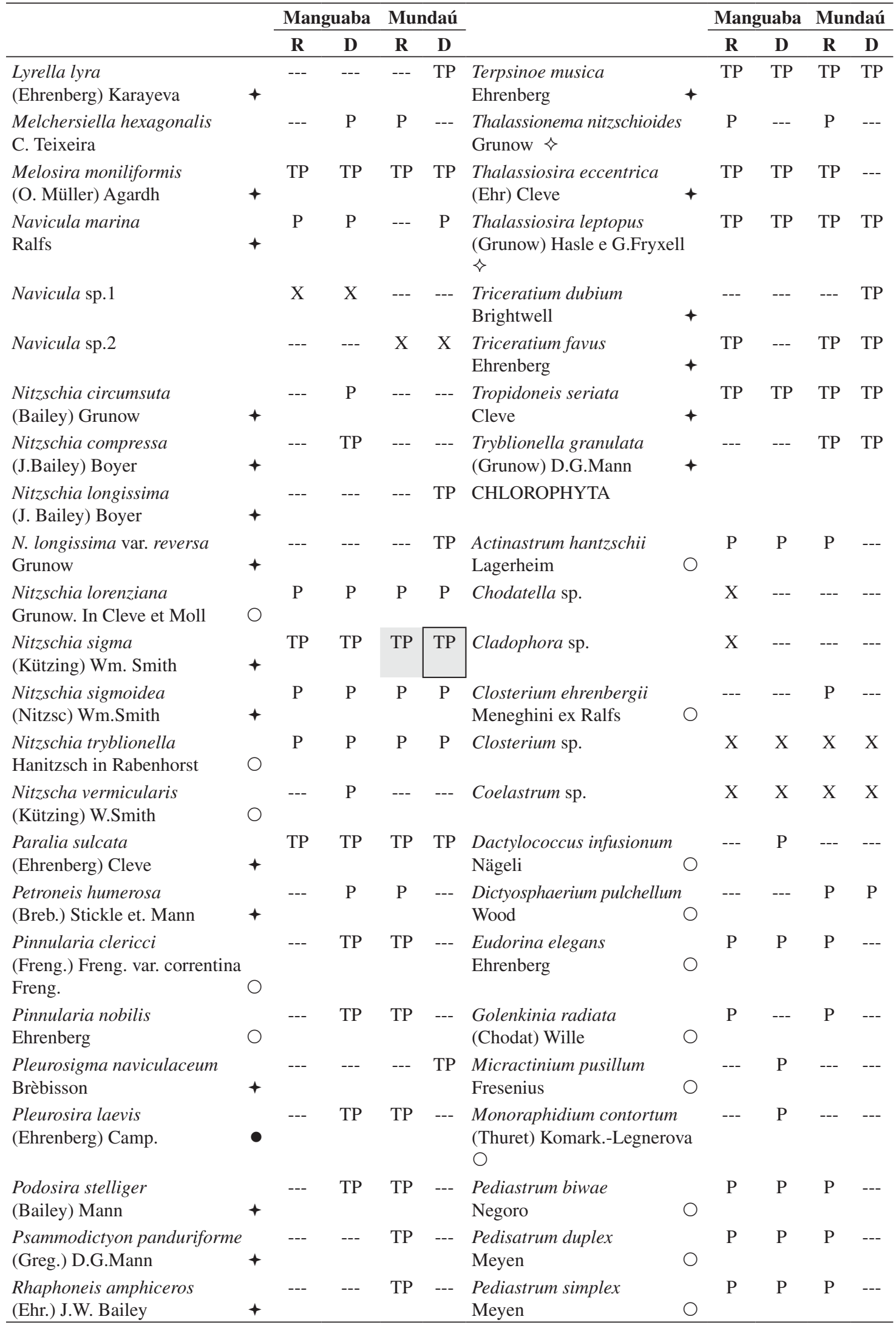


Table 1. Continued...

\begin{tabular}{|c|c|c|c|c|c|c|c|c|c|c|c|}
\hline & & \multicolumn{2}{|c|}{ Manguaba } & \multicolumn{2}{|c|}{ Mundaú } & & & \multicolumn{2}{|c|}{ Manguaba } & \multicolumn{2}{|c|}{ Mundaú } \\
\hline & & $\mathbf{R}$ & D & $\mathbf{R}$ & D & & & $\mathbf{R}$ & D & $\mathbf{R}$ & D \\
\hline $\begin{array}{l}\text { Rhizosolenia imbricata } \\
\text { Brightwell }\end{array}$ & $\diamond$ & $\mathrm{P}$ & $\mathrm{P}$ & $\mathrm{P}$ & $\mathrm{P}$ & $\begin{array}{l}\text { Scenedesmus acuminatus } \\
\text { (Lagerheim) Chodat }\end{array}$ & 0 & $\mathrm{P}$ & $\mathrm{P}$ & $\mathrm{P}$ & $\mathrm{P}$ \\
\hline $\begin{array}{l}\text { Rhopalodia musculus } \\
\text { (Kützing) Otto Müller }\end{array}$ & + & $\mathrm{TP}$ & $\mathrm{TP}$ & $\mathrm{TP}$ & $\mathrm{TP}$ & $\begin{array}{l}\text { S. dimorphus } \\
\text { (Turpin) Kützing }\end{array}$ & O & $\mathrm{P}$ & $\mathrm{P}$ & $\mathrm{P}$ & $\mathrm{P}$ \\
\hline $\begin{array}{l}\text { Skeletonema cf. costatum } \\
\text { (Greville) Cleve }\end{array}$ & $\diamond$ & $\mathrm{P}$ & $\mathrm{P}$ & $\mathrm{P}$ & $\mathrm{P}$ & $\begin{array}{l}\text { S. falcatus } \\
\text { Chodat }\end{array}$ & $\bigcirc$ & $\mathrm{P}$ & --- & $\mathrm{P}$ & --- \\
\hline $\begin{array}{l}\text { Surirella fastuosa } \\
\text { Ehrenberg }\end{array}$ & + & $\mathrm{TP}$ & $\mathrm{TP}$ & $\mathrm{TP}$ & $\mathrm{TP}$ & $\begin{array}{l}\text { S. quadricauda } \\
\text { (Turpin) Brébisson }\end{array}$ & 0 & $\mathrm{P}$ & $\mathrm{P}$ & $\mathrm{P}$ & $\mathrm{P}$ \\
\hline $\begin{array}{l}\text { S. fastuosa var. recendens } \\
\text { (Schmidt) Cleve }\end{array}$ & + & $\mathrm{TP}$ & --- & --- & --- & Scenedesmus sp. & & --- & --- & $\mathrm{X}$ & --- \\
\hline $\begin{array}{l}\text { Surirella febigerii } \\
\text { Lewis }\end{array}$ & + & $\mathrm{TP}$ & $\mathrm{TP}$ & $\mathrm{TP}$ & $\mathrm{TP}$ & $\begin{array}{l}\text { Sphaerocystis schroeteri } \\
\text { Chodat }\end{array}$ & $\bigcirc$ & --- & --- & $\mathrm{P}$ & --- \\
\hline $\begin{array}{l}\text { Surirella lineares } \\
\text { Smith }\end{array}$ & $\bigcirc$ & --- & --- & $\mathrm{TP}$ & --- & Spirogyra sp. & & $\mathrm{X}$ & --- & $\mathrm{X}$ & --- \\
\hline $\begin{array}{l}\text { Surirella robusta } \\
\text { Ehrenberg }\end{array}$ & $\bigcirc$ & $\mathrm{TP}$ & $\mathrm{TP}$ & $\mathrm{TP}$ & --- & Spondylosium sp. & & --- & --- & $\mathrm{X}$ & --- \\
\hline $\begin{array}{l}\text { Surirella rorata } \\
\text { Frenguel }\end{array}$ & + & $\mathrm{TP}$ & --- & $\mathrm{TP}$ & --- & Starurodesmus sp. & & --- & --- & $\mathrm{X}$ & --- \\
\hline
\end{tabular}

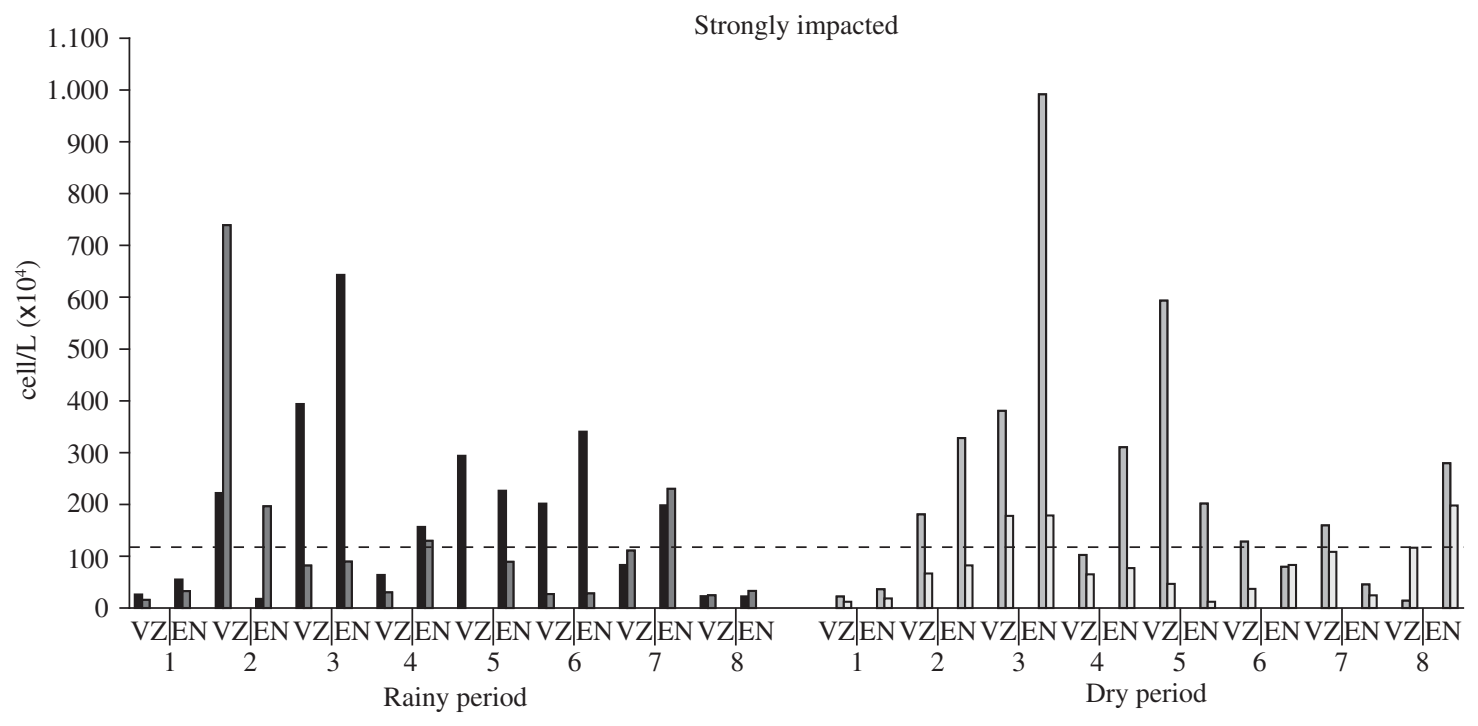

May $\square$ July $\square$ September $\square$ November

Figure 2. Distribution of the total phytoplankton density in Manguaba and Mundaú Lagoons in the rainy period (May and July/2002) and dry period (September and November/2002). 1-8 = collection stations; VZ = low tide; EN = flood.

microalga was only recognized in a study conducted at the channels of the Mundau/Manguaba EstuarineLagoon Complex by Melo-Magalhães et al. (2004a). In this study, the high importance of this diatom was again observed in Mundaú Lagoon as the species that forms blooms, being considered as a bioindicator in the referred ecosystem.
Planktonic cyanophyceae Anabaena spiroides and Microcystis aeruginosa were considered as dominant only in Manguaba Lagoon, with Anabaena spiroides dominating in the dry period and Microcystis aeruginosa in the rainy period.

The Microcystis species have a great ecological and public health importance, and due to their strategies, 
they exceed the growth rate of other microalgae, thus becoming dominant (Bitencourt-Oliveira, 2000). Such dominance of Microcystis is mainly a result of its fast vertical movement ability, which allows it to fully explore the water column and obtain more favorable luminosity conditions. Such cyanophyceae was mentioned, concerning the Mundau/Manguaba Estuarine-Lagoon Complex, by Melo-Magalhães and Navarro (1994), and subsequently, its qualitative importance was pointed out by Melo-Magalhães et al. (1998), who considered this species as dominant and very frequent at the discharge of Paraíba do Meio River (Manguaba Lagoon). Although it was considered as dominant in the Mundau/Manguaba Estuarine-Lagoon Complex Channels, this microalga was not frequent, as it was found in $16.7 \%$ of the samples (Melo-Magalhães et al., 2004b).

In this study, Microcystis aeruginosa was dominant in Manguaba Lagoon during the rainy period, present in $90 \%$ of the collected samples, while in Mundaú Lagoon this microalga was absent. The occurrence of this species in the state of Alagoas was mentioned, concerning the Estuarine-Lagoon System of Jequiá-AL, as little abundant species, but very significant regarding the occurrence frequency (Melo-Magalhães et al., 1996b), while in the Hydroelectric Power Plant Reservoir of Xingó, this cyanophyceae was considered as rare and sporadic (Melo-Magalhães et al., 2000). In different Brazilian water environments, the occurrence of at least 20 potentially toxic cyanophyta species has been observed, being Microcystis aeruginosa the most widely distributed species in Brazil (Sant'Anna and Azevedo, 2000).

The Anabaena spiroides species presents difficulties in moving vertically, but the presence of intracellular vacuoles allows the filaments to be within the euphotic zone and then benefit from the high concentrations of nutrients.

The occurrence of Anabaena spiroides was observed in the Mundau/Manguaba Estuarine-Lagoon Complex by Melo-Magalhães and Navarro (1994), but the quantitative importance of this microalga was pointed out by Melo-Magalhães et al. (1998) and Melo-Magalhães et al. (2004b).

In this study, Anabaena spiroides was present in Manguaba Lagoon, where it was considered as dominant in the dry period. It was also found in Mundaú Lagoon, but it showed insignificant quantitative importance.

The dynamics of the phytoplankton blooms are dependent on the interaction of physical, chemical and biological conditions, favorable to the development of this community, resulting in an explosive, self-limiting and short growth of one of few species, frequently producing visible coloring on the water bodies (Torgan, 1989; Paerl, 1988). Blooms of cyanophyceae species are commonly related to eutrophic environments, but there is usually a low correlation between cyanophyceae and nitrogen and phosphorus concentrations (Canfield Junior et al., 1989). The comparison between the optimum N:P ratio to eukaryotic cells and to cyanophyceae showed that the formation of cyanophyceae blooms requires a lower $\mathrm{N}: \mathrm{P}$ ratio than that required for the formation of eukaryotic cells. Therefore, the low ratio of nitrogen and phosphorous is more favorable to the formation of cyanobacteria blooms (Schreurs, 1992). Besides the contribution of these factors, the cyanophyceae also present a high number of special properties that determine their relative importance in the phytoplanktonic community.

This fact indicates that the Cyanophyceae blooms that occur in Manguaba Lagoon are favored by, among other factors, the high concentrations of nutrients, low salinity levels and a longer retention period of the waters from this lagoon. In Mundaú Lagoon, the higher penetration of marine waters allows higher levels of salinity and a shorter retention period, which are more favorable conditions to the development of diatoms.

In Mundaú and Manguaba Lagoons, during the studied periods, the average diversity ranged from 3.6 to 1.4 bits cell/L and decreased at the stations where blooms were observed of Anabaeana spiroides, Microcystis aeruginosa (stations 2 and 3); Cyclotella meneghiniana (station 4) and Skeletonema cf. costatum (stations 5 and 6).

In general, in the most impacted areas of both Mundaú and Manguaba Lagoons, the phytoplanktonic community presented low specific diversity, with predominance of opportunist species that caused flowering of Skeletonema cf. costatum diatom species at stations with higher salinity levels, and Microcystis aeruginosa and Anabaena spiroides cyanophyceae species at stations with lower salinity levels. Paerl (1991) refers to the cyanophyceae as a group of extremely opportunist algae that need the water column stability, intense illumination and constant temperature for their development and reproduction. According to Parsons et al. (1984), diversity can be very low under conditions of phytoplanktonic blooms.

At estuaries, the occurrence and distribution of the several groups of phytoplanktonic algae are influenced by the salinity, being the cyanophyta, chlorophyta and euglenophyta relatively more important at stations with low salinity levels, and then much better adapted to freshwater environments (Smayda, 1983).

The two lagoons showed a high number of species of freshwater origin. This fact reflects the higher influence of fluvial waters, mainly in Manguaba Lagoon, caused by, among other factors, the local topography, which suggests a more elevated water level in this lagoon than the sea level (Lima, 1990).

The dam landfill and the distance between the lagoon body and the dam mouth also make salty water penetration difficult at several stations of this lagoon.

Among the marine species found in this study, most were tychoplanktonic species. Such species, by living stuck to the substratum, can survive only in coastal regions of low depth, to the extent of sunlight penetration, and although they have mechanisms to adhere to different substrata, they can move through currents, tides 
and turbulence to more illuminated layers (Silva-Cunha, 2001; Siqueiros-Beltrons, 1988).

In general, even with the clear dominance of diatoms and r-strategist cyanophyceae, Mundaú and Manguaba Lagoons presented a varied microflora. These microalga groups were responsible for the formation of blooms that affected the lagoons in both studied periods, provoking an ecological imbalance, with consequent alterations to fish composition and production in the region, besides environmental deterioration due to recreational purposes.

The dynamics of the estuarine environment and the ability to import and export substances create a mixture system that keeps a great association of physical, chemical and biological components, generating high biological productivity rates and elevated levels of autotroph and heterotroph biomass (Nixon, 1981).

The density values obtained in Manguaba and Mundaú Lagoons in this study were very high, when compared to results obtained in other studies conducted at estuaries of the Brazilian northeast region by Lacerda et al. (1998), at the estuary of Paripe River (ItamaracáPE); Flores-Monte (1998), at Canal de Santa Cruz in Itamaracá-PE and by Melo-Magalhães et al. (2004a), at the channels of Mundau/Manguaba Estuarine-Lagoon Complex. Sendacz et al. (2006) presented data on zootoplankton biomass and trophic conditions in reservoirs in São Paulo state and conclude that different patterns of numerical densities and levels of biomass occurred with various trophic conditions. The results of this paper concur with the findings, as well as those of Pinto-Coelho et al. (2005). The high phytoplanktonic density values obtained in Mundaú and Manguaba Lagoons characterized the two lagoons as strongly impacted environments.

Acknowledgements - The authors thank the Fundação de Amparo à Pesquisa do Estado de Alagoas-FAPEAL for financial support.

\section{References}

ALAGOAS. Secretaria de Planejamento. Coordenação de Desenvolvimento Científico e Tecnológico., 1980. Projeto de levantamento ecológico cultural da Região das Lagoas Mundaú e Manguaba. 2ed. ampl. Maceió: Convênio SUDENE; CNRC.

BITTENCOURT-OLIVEIRA, MC., 2000. Development of Microcystis aeruginosa Kützing (Cyanophyceae/ Cyanobacteria) under cultivation and its taxonomic implications. Algological Studies, vol. 99, no. 1, p. 27-37.

BRANDINI, FP., LOPES, RM., GUTSEIT, KS., SPACH, HL. and SASSI, R., 1997. Planctologia na plataforma continental do Brasil: diagnose e revisão bibliográfica. Rio de Janeiro: FEMAR. 196p.

CANFIELD Jr., DE., PHLIPS, E. and DUARTE, CM., 1989. Factors influencing the abundance of blue-green algae in Florida lakes. Canadian Journal of Fisheries and Aquatic Science, vol. 46, no. 7, p. 1232-1237.
De LEÓN, L. and CHALAR, G., 2003. Abundancia y diversidad del fitoplancton en el Embalse de Salto Grande (Argentina Uruguay): ciclo estacional y distribución espacial. Limnetica, vol. 22 , no. $1-2$, p. 103-113.

EGGE, JK. and AKSNES, DL., 1992. Silicate as regulating nutrient in phytoplankton competition. Marine Ecology Progress Series, vol. 83, no. 1, p. 281-289.

ESKINAZI-LEÇA, E. and SANTANA, MR., 1977-1978. Diatomáceas da Laguna Mundaú (Alagoas-Brasil). Anais da Universidade Federal Rural de Pernambuco, vol. 2, no. 3, p. 181-206.

ESKINAZI-LEÇA, E., SILVA-CUNHA, MG., KOENING, ML., MACEDO, SJ. and COSTA, KMP., 1997. Variação espacial e temporal do fitoplâncton na plataforma continental de Pernambuco-Brasil. Trabalhos Oceanográficos da Universidade Federal de Pernambuco, vol. 2, p. 1-66.

FLORES- MONTES, MJ., MACEDO, SJ., KOENING, M. and CORREIA, IL., 1998. Variação nictemeral do fitoplâncton e elementos nutrientes no Canal de Santa Cruz, Itamaracá-PEBrasil. Trabalhos Oceanográficos da Universidade Federal de Pernambuco, vol. 26, no. 1, p. 13-26.

HASLE, GR., 1978. The inverted microscope methods. In SOURNIA, A. (Ed.). Phytoplankton manual. Paris: UNESCO. p. 88-96.

KINNE, O., 1970. Marine ecology. London: Wiley Interscience. p. 321-514.

LACERDA, SR., ESKINAZI-LEÇA, E. and KOENING, ML., 1998. Composição e variação da flora das diatomáceas no estuário do rio Paripe (Itamaracá-Pernambuco-Brasil). Trabalhos Oceanográficos da Universidade Federal de Pernambuco, vol. 26, no. 2, p. 19-30.

LIMA, IF., 1990. Maceió a cidade restinga: contribuição ao estudo geomorfológico do litoral alagoano. Maceió: EDUFAL. 255 p.

LOBO, EA. and LEIGHTON, G., 1986. Estrutura de las fitocenosis planctonicas de los sistemas de desembocaduras de rios y esteros de la zona central de Chile. Revista de Biologia Marina, vol. 22, no. 1, p. 143-170.

MARGALEF, R., 1991. Ecologia. 7 ed. Barcelona: Omega. 951p.

MELO-MAGALHÃES, EM. and NAVARRO, LFSBS., 1994. Levantamento preliminar da composição fitoplanctônica do complexo estuarino-Lagunar Mundaú/Manguaba (AlagoasBrasil). Boletim de Estudos Ciências do Mar, vol. 8, p. 65-72.

MELO-MAGALHÃES, EM., CAVALCANTI, MO. and LIRA, MCA., 1998. Florações de algas cianofíceas no Complexo Estuarino-Lagunar Mundaú/Manguaba-Al. Boletim de Estudos Ciências do Mar, vol. 10, p. 1-13.

MELO-MAGALHÃES, EM., CAVALCANTI, MO., GUEDES, EAC. and LIRA, MCA., 1999. Variação sazonal diurna do microfitoplâncton do Parque Municipal Marinho de Paripueira. Trabalhos Oceanográficos da Universidade Federal de Pernambuco, vol. 27, no. 1, p. 1-14.

MELO-MAGAlHÃES, EM., GUEDES, EA., LIRA, MCA. and CAVALCANTI, MO., 1996. Composição fitoplanctônica do sistema Estuarino-Lagunar de Jequiá, AL. Boletim de Estudos Ciências do Mar, vol. 9, p. 1-18. 
MELO-MAGALHÃES, EM., KOENING, ML. and NOQUEIRA, EMS., 2004b. Variação sazonal e espacial de algas cianofíceas no Complexo Estuarino Lagunar Mundau/ Manguaba, Alagoas-Brasil. Arquivos de Ciências do Mar, vol. 37, p. 63-76.

MELO-MAGALHÃES, EM., KOENING, ML. and SANT'ANNA, CL., 2004a. Fitoplâncton e variáveis ambientais nos canais do sistema estuarino lagunar Mundau/Manguaba, Alagoas, Brasil. Hoehnea, vol. 31, no. 1, p. 73-86.

MELO-MAGALHÃES, EM., LIRA, MCA., COSTA, FJCB. and SILVA, VB., 2000. Diversidade e variação espaçotemporal do fitoplâncton no reservatório da Usina Hidroelétrica de Xingo. Boletim de Estudos de Ciências do Mar, vol. 11, p. 1-14.

NIXON, SW., 1981. Remineralization and nutrient cycling in coastal marine ecossistems. In NEILSON, BJ. (Ed.). Estuaries and nutrients. Clifton: Humana Press. p. 111-138.

PAERL, HW., 1988. Nuisance phytoplankton blooms in coastal estuarine and inland waters. Limnology and Oceanography, vol. 33 , no. 2, p. 823-847.

PAERL, HW., 1991. Ecophysiological and trophic implications of light-stimulated amino acid utilization in marine picoplankton. Applied and Environmental Microbiology, vol. 57 , no. 2, p. 473-479.

PARSONS, TR., TAKAHASHI, M. and HARGRAVE, B., 1984. Biological oceanographics processes. 3 ed. Oxford: Pergamon Press. 320p.

PATRICK, R., 1967. Diatoms communities in estuaries. In LAUFF, GH. (Ed.). Estuaries. Washington: American Association for the Advancement of Science. p. 311-315.

PIELOU, EC., 1977. Mathematical ecology. New York: J. Wiley. 385p.

PINTO-COELHO, RM., BEZERRA-NETO, JF. and MORAIS Jr., CA., 2005. Effects of eutrophication on size and biomass of crustacean zooplankton in a tropical reservoir. Revista Brasileira de Biologia = Brazilian Journal of Biology, vol. 65, no. 2, p. 325-338.

ROUND, FE., 1981. The ecology of algae. Cambridge: Cambridge University. 747p.
SANT'ANNA, CL. and AZEVEDO, MTP., 2000. Contribution to the knowledge of potentially toxic Cyanobacteria from Brazil. Nova Hedwigia, vol. 71, no. 3-4, p. 359-385.

SANTELICES, B., 1977. Ecologia de algas marinas bentônicas: efeitos de fatores ambientais. Santiago de Chile: Pontifícia Universidade Católica do Chile. 487p. Documento de La Dirección General de Investigaciones.

SARDEIRO, MS. and ESKINAZI-LEÇA, E., 1985. Distribuição das Diatomáceas (Bacillariopyceae) na Plataforma Continental dos Estados de Alagoas e Sergipe (Brasil). In Anais da $8^{a}$. Reunião Nordestina de Botânica. Recife: Sociedade Botânica do Brasil. p. 33-56.

SARDEIRO, MS., 1987. Diatomáceas da Coroa do Segredo: Laguna Mundaú, Maceió-AL. Boletim de Estudos de Ciências do Mar, vol. 6, p. 92-102.

SASSI, R., 1991. Phytoplankton and environmental factors UN the Paraíba do Norte river estuary, northeastern Brazil: composition, distribution and quantitative remarks. Boletim Instituto Oceanográfico da Universidade de São Paulo, vol. 39, no. 2, p. 93-115.

SCHREURS, H., 1992. Cyanobacterial dominance: relations to eutrophication and lake morphology. Amsterdam: Università di Amsterdam. Tese de Doutorado.

SENDACZ, S., CALEFFI, S. and SANTOS-SOARES, J., 2006. Zooplankton biomass of reservoirs in different trophic conditions in the state of São Paulo, Brazil. Revista Brasileira de Biologia = Brazilian Journal of Biology, vol. 66, no. 1B, p. 337-350.

SHANNON, CE., 1948. A mathematical theory of communication. Bulletin of System Technology Journal, vol. 27, p. $379-423$

SILVA-CUNHA, MGG., 2001. Estrutura e dinâmica da flora planctônica no canal de Santa Cruz-Itamaracá(PE)-Nordeste do Brasil. Recife: Universidade Federal de Pernambuco. Tese de Doutorado.

SIQUEIROS-BELTRONES, DAS., 1988. Diatomeas bentonicas de la Laguna Figueiroa, Baja California. Ciencias Marinas, vol. 14 , no. 2 , p. $85-112$.

SMAYDA, TJ., 1983. The phytoplankton of estuaries. In KETCHUM, MH. (Ed.). Estuaries and Enclosed Seas. Amsterdam: Elsevier. p. 65-112.

TORGAN, LC., 1989. Florações de algas: composição, causas e conseqüências. Insula, vol. 19, p. 14-34. 